\section{GM gibberish}

\section{A roundup of global genetically} modified nonsense

- In April, a UK judge seemed to condone last year's uprooting of Monsanto's (St. Louis, MO) field trials in Oxford by protesters against genetically modified crops. The judge said he could not issue an injunction preventing the protest group GenetiX Snowball (Manchester, UK) from repeating its action, because the protesters may have a defense argument on the grounds that they are protecting public health. The judge ordered a full hearing, and issued a temporary injunction on six protesters, preventing them from continuing their campaign until the case is closed.

- Research from the University of Keele (Keele, UK) suggests that pollen from genetically modified (GM) plants could travel beyond 200 meters, the current buffer zone to prevent cross-pollination with wild-type plants required by European law. By planting sterile male rapeseed plants (i.e., unable to selfpollinate, the normal mode of rapeseed fertilization) next to GM rape and phenotyping the resultant seeds, the researchers were able to assess how far pollen from GM plants had traveled. At 400 meters, GM pollen had fertilized up to $7 \%$ of the seeds. The researchers acknowledge this is a "worst-case scenario" experiment. However, in earlier "realistic" experiments using normal, nonsterile plants capable of self-fertilization, the group showed that cross-pollination with GM plants did not occur using only a $150 \mathrm{M}$ buffer zone.

- Jumping on the GM banning bandwagon, two major global agricultural and food processing businesses pledged in April not to deal in genetically modified crops. AE Staley (Decatur, IL), a major US corn refinery and a subsidiary of the UK's Tate and Lyle (London) sugar producer, announced it would not trade in GM corn unapproved by the European Union. Archer Daniels Midland (Decatur, IL), one of the largest agriculture businesses in the US, followed suit a week later.

- In a far from charitable report, Christian Aid (London), has taken a swinging swipe at biotechnology's admittedly paltry efforts to "feed the world." Christian Aid (motto, "We Believe in Life before Death") is one of the largest UK charities offering aid to the developing world. Its report released in mid-May, "Selling Suicide: Farming, false promises, and genetic engineering in developing countries" bears both the tone and the content of other anti-genetic engineering literature. It contains quotes from "experts" who provide varying degrees of insight into plant biotechnology. The head of India's National Research Centre on Plant Biotechnology, V.L. Chopra, for instance, has apparently come to the somewhat astounding conclusion that "Monsanto are in it for the profit."

\section{UK science minister studies growth limiting factors}

At the end of April the UK minister for science, nies wanting to establish manufacturing faciliLord Sainsbury, launched a fact-finding mis- $\quad$ ties in these areas are restricted by space. "We sion to highlight possible barriers to the development of biotechnology firms in the UK. As part of the initiative, Sainsbury and his team of five industry experts including Chris Evans, chair of the newly merged venture capital firm Merlin Bioscience (see p. 528), are focusing on the problems facing clustersgroups of biotechnology firms formed through university spinouts with links to investors for funding. (The majority of the UK's biotechnology firms are based in clusters around Oxford, Cambridge, and Edinburgh.) However, compa-

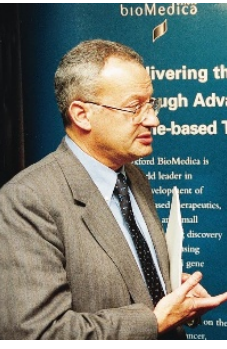

Lord Sainsbury don't want companies to be forced to move, as this will cause the cluster to break down," explains Peter Nolan, chair of Oxfordshire Biolink-formerly with the Department of Trade and Industry (DTI; London), and also director of operations at Oxford Biomedica (Oxford, UK)—which was established in April to network the Oxford cluster firms, helping them to develop faster through voluntary sharing of experience and business knowledge. Sainsbury's findings and recommendations, expected to be published next month, will be implemented by the DTI.

\section{Biomarkers get FDA nod}

Officials at the US Food and Drug Administration (FDA; Rockville, MD) are seeking to expand their use of biomarkers for evaluating drugs. The FDA already largely relies on biomarkers for evaluating drugs for treating HIV, according to Donna Mildvan of Beth Israel Medical Center (New York). She was speaking at a mid-April meeting, "Biomarkers and Surrogate Endpoints: Advancing Clinical Research and Applications," held at the US National Institutes of Health (NIH; Bethesda, MD). No one doubts that biomarkers are revolutionizing clinical research," says Scott Zeger of Johns Hopkins University School of Hygiene and Public Health (Baltimore, MD), noting that biomarkers are used as a substitute measure for clinical end points during therapeutic trials. Stepped-up efforts are under way to expand that success into other clinical areas involving diseases such as cancer and CNS disorders, according to NIH director Harold Varmus, who has been meeting periodically since 1997 with industry representatives to encourage that expansion. "The need for newer biomarkers is a bottleneck in drug development," he says.

\section{E\&Y advise communication}

Ernst \& Young (E\&Y; The Hague) released its annual European Life Sciences report in April, entitled "Communicating Value." The report's most important message, according to E\&Y partner William Powlett Smith, is that companies must be careful in informing their shareholders about the value of the research they are conducting. A lack of accurate communication is blamed for last summer's collapse of British Biotech (Nature Biotechnology 16, 503, 1998). The demise of British Biotech (Oxford, UK), along with three other leading companiesBiocompatibles (Farnham, UK), Cortecs (Cambridge, UK) (Nature Biotechnology 17, 12, 1999), and Scotia (Stirling, UK) — was the primary cause of the UK bioscience devaluation over the year to 1994 levels, says the report. However, E\&Y notes that, before their collapse, these firms accounted for more than $50 \%$ of the total value of the UK public sector, obscuring the success of other European companies. Pharming (Leiden, The Netherlands), for example, raised \$70.8 million through an initial public offering on Easdaq in February 1998.

\section{Natrecor fails, stock plummets}

In a move that went against the recommendations of its own advisory panel in January, the US Food and Drug Administration (FDA; Rockville, MD) decided on April 27 not to approve Scios's (Mountain View, CA) Natrecor nesiritide for the treatment of acute congestive heart failure, prompting a $61 \%$ drop (to \$3.75) in Scios's share price. The FDA acknowledged Natrecor's efficacy in clinical trials, but had concerns over the incidence of hypotension. Scios president and CEO, Richard Brewer, says he expects eventually to get FDA approval for Natrecor once additional studies are done. "We know it works, which is a more than a lot of people know about their drugs," says Brewer. Scios's partner Bayer AG (Leverkusen, Germany), which has a worldwide license to market Natrecor, will fund any additional clinical studies. Natrecor is a recombinant form of $\beta$-type natriuretic peptide, which is naturally produced by the heart ventricles during heart failure. It increases blood flow through the heart by dilating blood vessels, ridding the body of salt and water, and decreasing the levels of other hormones that raise blood pressure. Natrecor was Scios's first NDA since the company's founding in 1981. 